\title{
Study on Clinical Mastitis (Bacteriological) in She-Camels (Camelus dromedarius) in Some Areas of Middle Euphrates in Iraq
}

\author{
Y.I. Kh. AL-Tofaily M. A. N. Al rodhan \\ Coll. of Vet. Med/ Univ. of Al-Qadissiya
}

\begin{abstract}
The lack of information about mastitis in camels in Iraq has stimulated this research in desert lands of AL-Najaf and Al-Qadissiya provinces. The study is concerned with determining the overall infection, percentage of clinical mastitis according to age, stages of lactation and the number of calving, as well as detection the susceptibility of isolated microorganism to the antimicrobial drugs. 402 quarters of 141 lactating she-camels were examined.Result of this study show that percentage of clinical mastitis was $5.22 \%$ and $11.35 \%$ for quarters and animals respectively. $23.81 \%$ and $18.75 \%$ of quarters and animals respectively were showed acute form of mastitis, whereas $57.15 \%$ and $56.25 \%$ which identified as chronic form for quarters and animals respectively, also result showed that $19.04 \%$ samples identified as bland teats.Gram positive bacterial isolates was (76.19\%) including Staphylococcus aureus, Staphylococcus hycus, Streptococcus agalactiae, Micrococcus luteus, Arcanobacterium pyogenes, whereas gram negative bacterial isolates was $(23.8 \%)$ which included Mannhiemia haemolytica Salmonilla spp and, Klibcilla pneumonia. The results of study showed that varieties of ages and number of calving were not significant differences $(\leq 0.01)$ on clinical mastitis in Iraqi she-camels.Antimicrobial drugs against bacterial isolates showed high susceptibility to Ciprofloxacin, Doxycycline, sulphthazin/Trimethiprim, Gentamicin, and Tetracycline, others antimicrobial Chloramphenicol, and Streptomycin showed moderate sensitivity, while all bacterial isolates were found resistant to Ampicillin, Erthromycine and Trimethiprime.
\end{abstract}

\section{Introduction}

Camels can lactate even under severe drought conditions, this ability to retain lactation even when dehydrated and during times of drought, because water is not absorbed from the mammary gland in order to conserve body water and the milk becomes more diluted, a phenomenon which is hormonally controlled ${ }^{(1,}{ }^{2)}$.Mastitis is a complex disease occurring world-wide among dairy animals, with heavy economic losses ${ }^{(3)}$, it can be defined as inflammation of parenchymal tissue of the mammary gland, regardless of cause, it is therefore characterized by a range of physical and chemical changes in milk and pathological changes in the glandular tissue, there are swelling, heat, pain, and edema in mammary gland in clinical cases, the most important changes in milk include discoloration, presence of clots and presence of large number of Leukocytes $^{(4)}$.In Camelidae, although camels are reported to be relatively resistant to mastitis, few reports are available in literature, mastitis is a major problem, and deserves further attention owning to its potential impact on milk production affecting food security in arid and semiarid area ${ }^{(5,6)}$. There are various studies had been conducted worldwide on the isolation and identification of bacterial organisms in mastitic camel milk. From these studies can be assumed that Staphylococcus aureus, Streptococcus agalactiae, Klebsiella pneumoniae might be responsible for mastitis in camels $^{(7)}$.Gram-positive bacteria, Staphylococcus aureus, Micrococcus spp., Streptococcus spp. and Corynebacterium spp were the major isolates from camel milk samples and it was the most predominant bacterial isolates ${ }^{(8,9)}$.

* Contagious pathogens: - when the udder is the reservoir of infection, Streptococcus agalactiae and staphylococcus aureus were ranked as infectious pathogens.

* Environmental pathogens: - when the environment is the source of infection, which involved group D streptococci, Streptococcus dysgalactiae, Coagulase negative staphylococci (CoNS), Coliforms and Micrococci ${ }^{(10)}$. Reported $^{(11)} 23$ acute and 6 subclinical cases of mastitis out of total of 94 lactating dromedaries in the U.A.E. They isolated different bacterial organisms from 28 
milk samples as Bacillus cereus(7), Streptococcus uberis (5),Streptococcus agalactiae (4),Diplococcus pneumoniae (4), Staphylococcus aureus (3), Escherichia coli (3) and also Candida albicans (1).Staphylococcus aureus, Streptococcus agalactiae and coagulase negative staphylococci seem to be important pathogens in the mastitic camel as in other dairy animals $^{(12)}$.Clinical signs of mastitis of camels were $21 \%$, a visible signs of inflammation

\section{Materials and Methods}

A) Animals of study

Four hundred two lactating quarters of 141 lactating she-camels have been examined for clinical mastitis in camels herds which were kept by nomadic pastoralists under traditional management.

Information of age, lactation stage and number of calving has been recorded.

All she-camels that showed clinical mastitis have been subjected to clinical examinations such as temperature, plus rate, respiratory rate and appetite.

Clinical examinations of udder have been carried out according to $(16,17)$

B) Collection of samples

Collection of samples, prior to sampling cleaning the udder wall, the udder was washed by sprayed with iodine solution and dried with cotton and the tips of teats were cleaned with cotton moistened with $70 \%$ alcohol, Samples collected in sterile universal bottles and transported the samples in ice box and reached the laboratory in Al-Qadysia University within 24h. ${ }^{(18,13)}$

Depended on $(17,19)$ the milk samples were examined for their consistency, color and other visible abnormalities. Clinical mastitis was recognized by abnormal milk, signs of udder infection and detection of mastitis pathogens by bacteriological culture; whereas,

C) Culturing:

All milk samples were cultured on blood agar and MacConky agar and incubated at $37 \mathrm{C}^{\circ}$ for following included acute and edematous swelling of udder and formation of pus in the mammary exudates resulting in a visible alteration of milk $^{(13)}$.

Same result reported in Ethiopia by ${ }^{(14)}$ who study the prevalence and bacterial causes of mastitis, $10.2 \%$ were positive for clinical mastitis, Stated ${ }^{(9)}$ that found high prevalence $19(12.5 \%)$ were diagnosed as clinical cases of mastitis based on clinical signs and bacteriological

24-48 hrs.Media used for bacterial isolation from milk samples .Prepared according to manifucturory instraction by dissolving of powder of media in 1 litter of distal water, Blood agar40 gm $/ 1 \mathrm{~L}, 64.5 \mathrm{gm} / 1 \mathrm{~L}$, bile asculin agar $64.5 \mathrm{gm} / 1 \mathrm{~L}$, nutrient agar $28 \mathrm{gm} / \mathrm{L}$, nutrient broth $12 \mathrm{gm} / \mathrm{L}$, TSI $24.28 \mathrm{gm} / 1 \mathrm{~L}$, Staph 110 agar $149.5 \mathrm{gm} / 1$ Liter, Mannitol salt agar. $111 \mathrm{gm} / 1 \mathrm{Liter}$, MacConky agar. 51.5gm /1Liter, Brain heart infusion agar. $149.5 \mathrm{gm}$ /1Liter, Methyl red -Voges -Proskauer medium (MR-VP medium). 17gm /1Liter,Diagnosis depend on morphological character (shape ,color and size ) of colony, then suspected isolates subculture on MacConky agar and examined via gram stain, also cultured on slant nutrient agar for biochemical testing .Presumptive identification of bacterial isolates was made based on the

D) Gram Stain (Biowold /KSA)

E) Biochemical tests:- biochemical tests were used in this study were Catalase test, Oxidase test, Coagulase test (Slide Coagulase test and Tube Coagulase test), Urease test, Indol test, Methyl red test and Voges-Proskauer test.

F) Kits of Identification system for bacteria:-

API Staph, API Coryne API 20 and Strepto (biomerinex/Farnce). and

Mastastaph Kit, Mastastrep Kit (Lancefield groups) (Manassas, Virginia/ USA)

Identification of isolates:-

Diagnosis have been done according to ${ }^{(20)}$

\section{Results}

The results show that percentage of clinical mastitis of total examined she-camels was $5.22 \%$ were included acute, chronic and bland teats quarters were $23.81 \%, 57.15 \%$ and $19.04 \%$ of quarters respectively, Out of 141

animals were $11.35 \%$ showed udder affections, divided as $18.75 \%$ she-camels were suffered from acute form, $56.25 \%$ were showed chronic mastitis and $25 \%$ were showed bland teats (Table 1). 
Table (1): The number and percentages of clinical mastitis in she-camels

\begin{tabular}{|l|l|l|l|l|}
\hline \multirow{2}{*}{ categories } & \multicolumn{2}{|l|}{ Quarters } & \multicolumn{2}{l|}{ She-camels } \\
\cline { 2 - 5 } & No & $\%$ & No & $\%$ \\
\hline Acute mastitis & 5 & 1.24 & 3 & 2.12 \\
\hline Chronic mastitis & 12 & 2.98 & 9 & 6.38 \\
\hline Bland teats & 4 & 0.99 & 4 & 2.83 \\
\hline total & 21 & 5.22 & 16 & 11.35 \\
\hline
\end{tabular}

1)-A cute mastitis

A cute mastitis was recorded as $1.24 \%$, the clinical sign of this form of mastitis which investigated were characterized by edematous, swelling, redness and there were pain during palpation, and visible alteration of the color and consistency of milk which was watery and contained clot, the animals showed slightly systemic reaction, there was slightly increased of body temperature $37.5 \mathrm{C}^{\circ}$ and slightly elevated pulse rate, other cases characterized by slight pain, moderate enlargement of mammary glands and there were very little serous exudates during milking, there were no systemic reaction, (Photo 1 ).

2)-Gangrenous form of mastitis

Diagnosed in she-camel showed the enlargement, redness of udder and darkness end of teats, restlessness, poor appetite, fever, (Photo 2), teats strips of this case were watery, bloody-tinged, bacterial isolation and identification showed Mannhimia haemolytica was associated with this form of mastitis.

3)-Chronic mastitis

The results were revealed that $2.98 \%$ quarters were showed chronic form of mastitis; the overall signs were chronic obstructive mastitis which was characterized by massive dilatation of quarter and accumulation of dried pus, exudates or mastitic milk. Obstruction of the teat canal and hypertrophy of the teat were constantly detected (Photo 4). Some cases were showed chronic suppurative mastitis; the affected quarter was enlarged with deformity of teat position, firm and coarsely nodular (picture 5). Teat fistula and rupture of enteric udder obsesses were observed and revealed creamy white pus secreted during sampling (Photo 3). Other form of chronic mastitis diagnosed was Chronic non suppurative mastitis characterized by firm, atrophied and painless of affected quarter, pus with serous yellow fluid. There were high proportion of wound and scar tissue on teat or udder were seen, most she-camels were showed one infected quarter and little were showed more.

She-camels having chronic mastitis infection showed no systemic reactions; normal body temperature $(36.3 \pm 0.2) \mathrm{C}^{\circ}$, respiratory rate $(15 \pm 2)$ per minute, pulse rate $(45 \pm 3)$ per minute, good appetite, good rumination, and pink mucous membrane.The study has been also showed that there were $0.99 \%$ bland teats from total examined quarters characterized by obstruction of teat canal and nonproductive quarter.The results revealed among 21samples found positive for bacterial isolation, $76.19 \%$ samples revealed gram positive bacteria were the major isolates comprising of $S$. aureus, $S$. hyicus, Micrococcus luteus, S. agalactiae, Arcanobactrium pyogenes were represented with $(28.57 \%),(14.28 \%),(9.52 \%),(4.76 \%)$ and $(19.04 \%)$ respectively, whereas gram negative bacteria was $23.8 \%$ of bacterial isolates ranked as Mannheimia haemolytica, Salmonella spp and $K$. pneumonia were (9.52\%), (9.52\%) and (4.76\%) respectively(Table 2 ). 
Table (2): Bacteria genus isolated from clinical mastitis.

\begin{tabular}{|l|l|l|}
\hline \multirow{2}{*}{ Isolate } & \multicolumn{2}{|l|}{ Clinical cases } \\
\cline { 2 - 3 } & No & $\%$ \\
\hline & & \\
Staphylococcus aureus & 6 & 28.57 \\
Staphylococcus hicus & 3 & 14.28 \\
Streptococcus agalactiae & 2 & 9.52 \\
Micrococcus luteus & 1 & 4.76 \\
Arcanobacterium pyogens & 4 & 19.04 \\
Salmonella spp & 2 & 9.52 \\
Klebsiella pneumoniae & 1 & 4.76 \\
Mannheimia haemolytica & 2 & 9.52 \\
& & \\
\hline Total percentage & & \\
\hline
\end{tabular}

The age of camels examined varied from 5 to 25 years, the results showed that shecamels of $5-10$ years, $11-15$ years and $\geq 16$ years old were represent with Occurrence of clinical mastitis at she-camels of were $12.5 \%$,
$10.25 \%$ and $9.09 \%$ respectively, Statically the results showed that there are no significant differences $(\mathrm{P} \leq 0.01)$ among groups of ages Table (3).

Table (3): the relationship between the age and occurrence of clinical mastitis.

\begin{tabular}{|r|r|r|}
\hline \multirow{2}{*}{ Age } & \multicolumn{2}{|}{ Clinical } \\
\cline { 2 - 3 } & No & $\%$ \\
\hline $5-10$ & 10 & 12.5 \\
\hline $11-15$ & 4 & 10.25 \\
\hline 16 - above & 2 & 9.09 \\
\hline Total & 16 & 11.34 \\
\hline
\end{tabular}

The results of study showed that the 4 of calving were 9.52\%, 4.76\%, $16.12 \%$ and relationship between the number of calving $12.76 \%$ respectively, statically there are no and occurrence of mastitis were recorded that significant differences $(\mathrm{P} \leq 0.01)$ among the occurrence of clinical mastitis of $1,2,3$, and $\geq \quad$ numbers of calving. Table (4).

Table (4): the relationship between clinical mastitis and calving numbers.

\begin{tabular}{|r|r|r|}
\hline Number of & \multicolumn{2}{|r|}{ Clinical } \\
\cline { 2 - 3 } calving & No & $\%$ \\
\hline 1 & 4 & 9.52 \\
\hline 2 & 1 & 4.76 \\
\hline 3 & 5 & 16.12 \\
\hline 4-above & 6 & 12.76 \\
\hline Total & 16 & 11.34 \\
\hline
\end{tabular}


The results of stages of lactation and clinical and subclinical mastitis were affected on mastitis occurrence were recorded as that proportions of mastitis occurrence of clinical mastitis were $10.38 \%, 13.04 \%$ and $11.22 \%$ at 1day-3mouths, 4-6 mouths and $\geq 7$ mouths of lactation stages respectively, statically there are no significant differences between divided lactation stages $(\mathrm{P}<0.01)$, Table $(5)$.

Table (5): the relationship between clinical and stages of lactation.

\begin{tabular}{|r|r|r|}
\hline Lactation & \multicolumn{2}{|}{ Clinical } \\
\cline { 2 - 3 } stages & No & $\%$ \\
\hline $1 \mathrm{~d}-3 \mathrm{~m}$ & 8 & 10.38 \\
\hline $4 \mathrm{~m}-6 \mathrm{~m}$ & 6 & 13.04 \\
\hline $7 \mathrm{~m}$ - above & 2 & 11.22 \\
\hline Total & 16 & 11.34 \\
\hline
\end{tabular}

Results of antimicrobial susceptibility test Table (6) showed the results of antimicrobial susceptibility tests have been done to the bacterial isolates of mastitis she-camels diagnosed in this study and demonstrated the high susceptibility to Ciprofloxacin and Doxycycline which had have high mean value $(100 \%)$ for each one. as well as other antibiotics which come below in activity sulphthazin /Trimethiprim, Tetracycline, Gentamicin and Chloramphenicol were 97.9\%, $97.9 \%, 90.6 \%$ and $90.6 \%$ respectively, and others antimicrobial drugs showed moderate sensitive was Streptomycin $71.8 \%$ whereas high level of resistance of mastitis pathogens was recorded against Ampicillin, Erthromycine and Trimethiprime were $49.9 \%, 41.6 \%$ and $11.4 \%$ respectively.

Table (6) Results of Antimicrobial Susceptibility of bacterial isolates

\begin{tabular}{|c|c|c|c|c|c|c|c|c|c|c|c|}
\hline Microorganism & No & 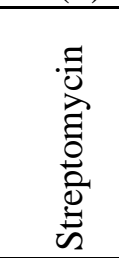 & 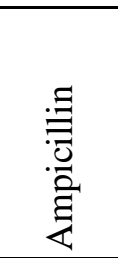 & 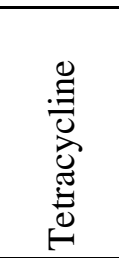 & 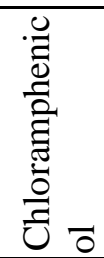 & 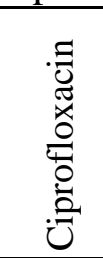 & 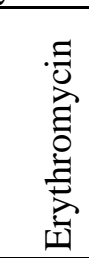 & 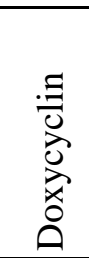 & 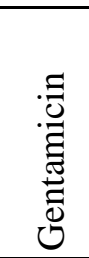 & 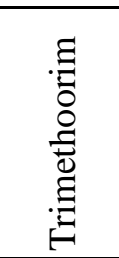 & 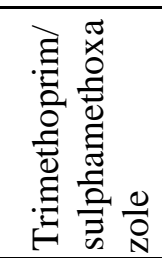 \\
\hline S. aureus & 6 & 66.6 & 83.3 & 83.3 & 83.3 & 100 & 16.6 & 100 & 83.3 & 33.3 & 83.3 \\
\hline S. agalactiae & 2 & 100 & 50 & 100 & 100 & 100 & 0 & 100 & 100 & 0 & 100 \\
\hline S. hycus & 3 & 33.3 & 66.6 & 100 & 66.6 & 100 & 66.6 & 100 & 66.6 & 3.33 & 100 \\
\hline M. luteus & 1 & 100 & 100 & 100 & 100 & 100 & 100 & 100 & 100 & 0 & 100 \\
\hline A. pyogens & 4 & 75 & 50 & 100 & 75 & 100 & 50 & 100 & 75 & 25 & 100 \\
\hline Salmonella spp & 2 & 100 & 50 & 100 & 100 & 100 & 0 & 100 & 100 & 0 & 100 \\
\hline K. pneumoniae & 1 & 100 & 0 & 100 & 100 & 100 & 100 & 100 & 100 & 0 & 100 \\
\hline M. haemolytica & 2 & 0 & 0 & 100 & 100 & 100 & 0 & 100 & 100 & 0 & 100 \\
\hline Total percentage & 21 & $71.8 \%$ & $49.9 \%$ & $97.9 \%$ & $\begin{array}{l}90.6 \\
\%\end{array}$ & $100 \%$ & $\begin{array}{l}41.6 \\
\%\end{array}$ & $\begin{array}{l}100 \\
\%\end{array}$ & $\begin{array}{l}90.6 \\
\%\end{array}$ & $11.4 \%$ & $97.9 \%$ \\
\hline
\end{tabular}




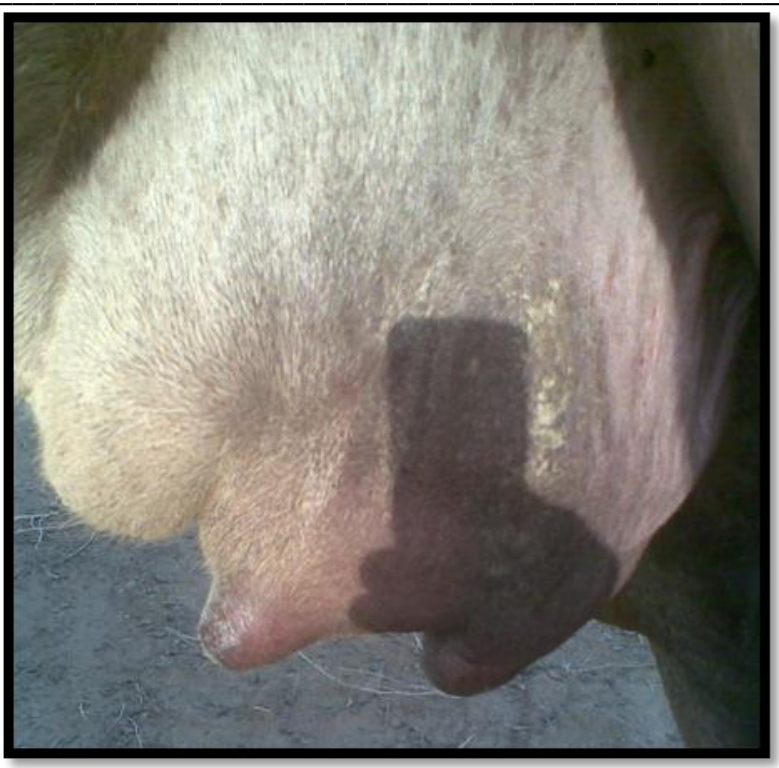

Photo (1):acut edematus and swelling mastitis in she-camel.

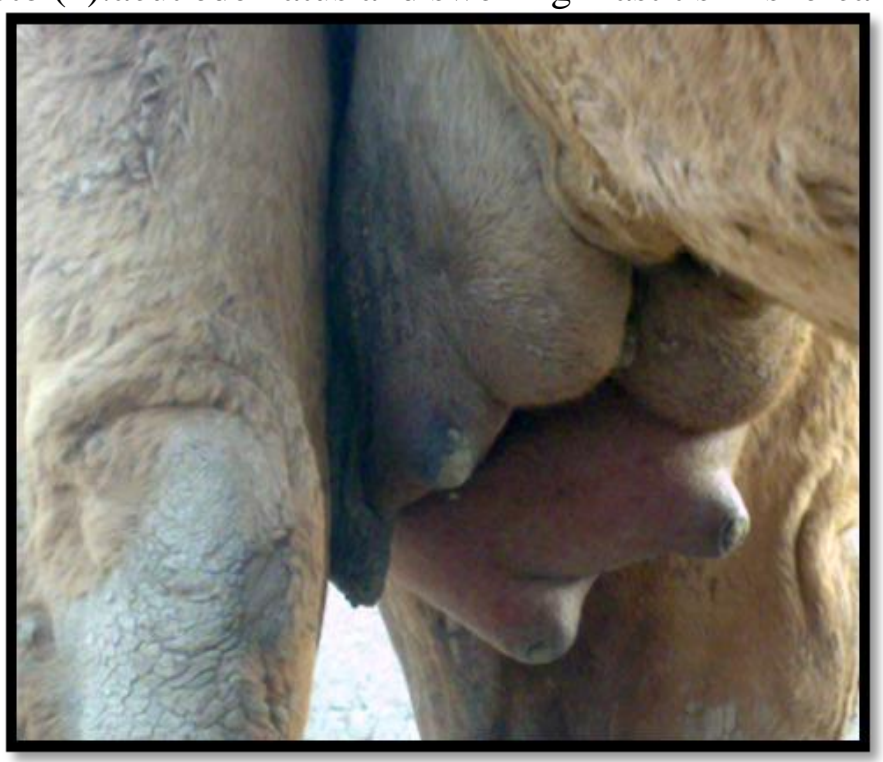

Photo (2):Gangerenus mastitis in she-camel

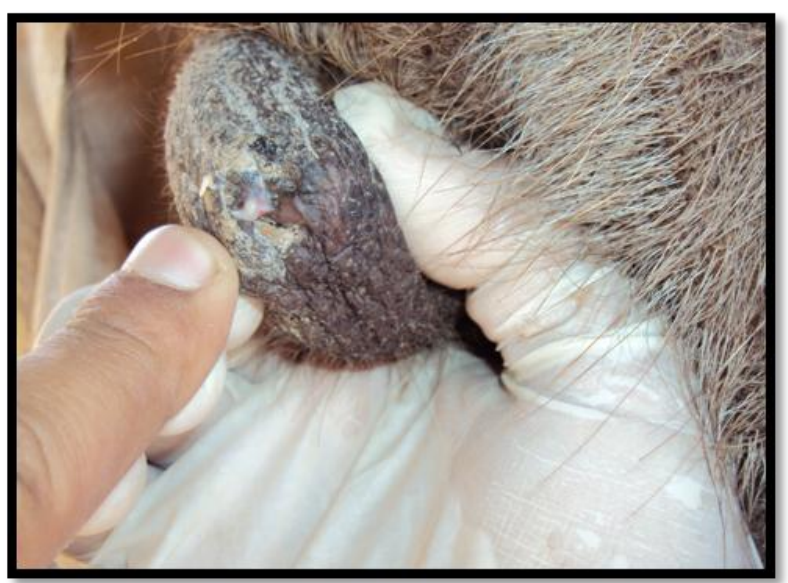

Photo (3):Chronic mastitis with teat fistulla in she-camel 


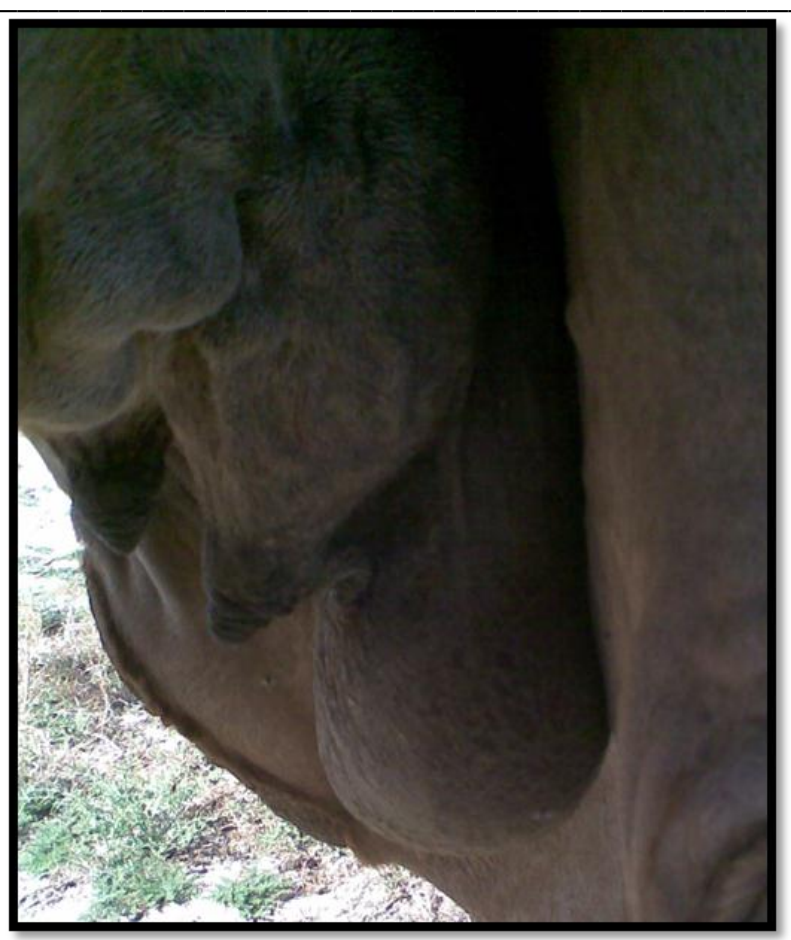

Photo (4): chronic obstractive mastitis in she-camel

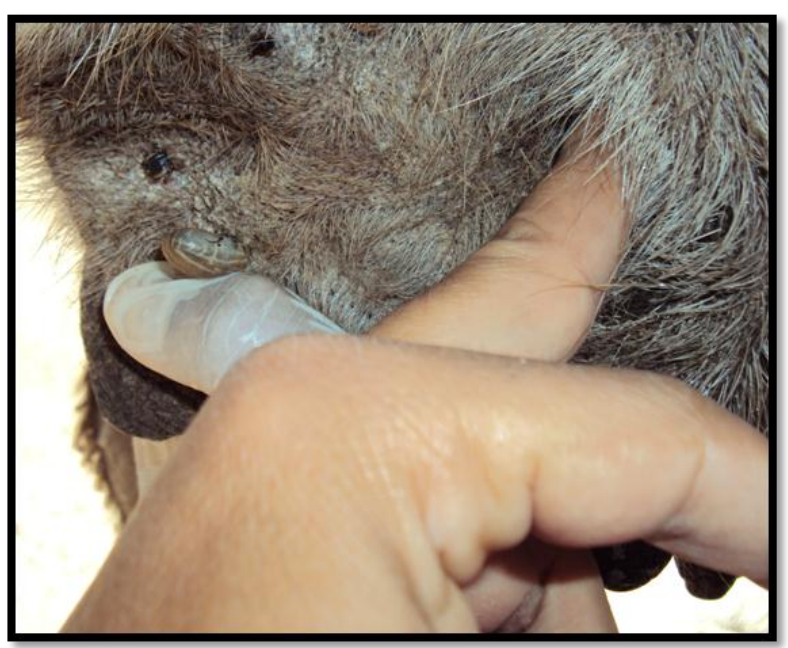

Photo (5): chronic atryphoid and nodular mastitis in she-camel

\section{Discussion}

The prevalence of clinical mastitis in she camels in present investigation was $(5.22 \%)$ this percentage was lower than results reported by ${ }^{(14}$, $13)$ as $10.2 \%$ and $21 \%$ respectively, but it is almost close to some previous studies as $8.3 \%$ by (21). Camels that used in milk production (dairy camels) usually have high prevalence of mastitis, whereas Iraqi camels not used for milk production but this percentage which recorded result to the disease is unconsidered and medically neglected in Iraqi pastoralists and nomad, as well as nomads in Iraq keep other animals such as sheep and goats which could be sources of mastitis pathogens.On other hand, this prevalence very low compared with that reported in cow $(52-78 \%)^{(22),}$ there might be several reasons why mastitis was more uncommon in camelids than in other domesticated animal species used for milk production. The mammary glands of she-camel possess four quarters and one teat per quarter. Each teat has 2-3 streak canals that enter into separate teat and gland cisterns. Each teat is associated with a sperat double gland. The streak canals are very narrow and a $1 \mathrm{~mm}$ tomcat catheter is required for penetration. This twin duct anatomy with its narrow streak canals might in some way protect against infection ${ }^{(23,24)}$. Also the anatomical structure of much more long limbs compared with 
cattle that lead to raise the udder from the ground until when sitting the animal, and the dry nature of feces of camel and environment .However, camel milk have found substances that inhibit the growth of pathogenic bacteria, these inhibitors are proteins in nature and have been described as lysozyme, immunoglobulins, lactoferrin and lactoperoxidase, these proteins have been shown to with higher potential and concentrations in

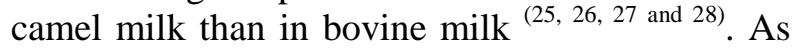
will as there were differences in the nature environments between camels and cow that which characterize by less contaminators than cattle environment. The using of antisuckling devices in Iraqi camels is practiced when young calves older than six mounths are herded together with their dams, it as non-traumatic devices used a protecting harness made of rope named "Shmella" could serve alternatively to reduce injury incidence.Acute and Gangrenous forms of mastitis diagnosed in she-camel depending on obvious clinical signs and the visible alteration of the milk, that agreement with, ${ }^{(29,6)}$ have been described the gangrenous mastitis with lymph node enlargement in the camel with acute cases, the mammary secretions are watery, yellowish or blood tinged.Chronic obstructive mastitis was characterized by dilatation of the cistern and obstruction of the teat canal which might be the predisposing factor followed by invasion of the etiological agent Staphylococcus spp, Streptococcus spp and Arcanobacterium pyogenes were similar finding for $(30,31$ and 28$)$ they were mentioned chronic unilateral mastitis in dromedaries' lactiferous ducts blocked by accumulations of keratin. This obstruction caused a cease in milk production, enlargement of the affected quarter.Chronic suppurative mastitis reported in our study was most commonly detected in the camel by several authors ${ }^{(32,33)}$. Chronic suppurative mastitis was found to be similar to summer mastitis in cow $^{(34)}$. Teat fistula and lesion on udder also detected in this study that similar to ${ }^{(14,5)}$ they suggested the teat lesions caused by tick infestation, as well as use of antisuckling devices could predispose the udders to bacterial infections, which persist as chronic infections. In our study udder lesion may be occurs by accidental penetrated wound by robbing the animal their udder by hard plants, tick infestation or happened by rupture udder abscess. Also in Iraqi dromedarius the tick infestation, mismanagement as hand milking and the weaning time, they are play an important role as a predisposing factors in occurrences of mastitis, the disease is not usually treated and will often take a natural course to chronicity resulting in permanent loss of milk production.Most of acute mastitis occurs at weaning time when the camel calves separated from their dames at weaning time, accumulation of milk in udder increase the chance of udder invasion by bacteria and mastitis is occurring.The Gram-positive cocci were the main pathogens isolated from camel mastitic milk samples constituting $76.19 \%$ of the total isolates. Many authors also reported that these pathogens are major mastitis causing agents in she-camels with mastitis ${ }^{(12,35)}$.The results of this study indicated that Staphylococcus aureus was the main isolated bacterium from cases of clinical and subclinical mastitis $(14.6 \%)$, the high rate of isolation of staphylococcus aureus of acute, chronic and subclinical mastitis of animals might indicate the wide distribution of this organism in nature and consequently causes many diseases, also may be Staphylococcus aureus are difficult to eliminate. Average cure rates have been reported to be only about $55 \%(26 \%-92 \%)$ for clinical cases $^{(4)}$. However, the increase number of staphylococci and other major mastitis pathogens could be attributed to the lack of supply and infrequent use of antimicrobials, and the inaccessibility of the camel owners in urban and preurban areas. The relatively high incidence of recovery of $A$. pyogenes (10.5\%) from chronic mastitis my reflect importance of this organism as main skin inhabitant organism and ability to inducing chronic suppurative lesions, this results was a line with ${ }^{(35,36)}$ whom found that $S$. aureus and $A$. pyogenes were the main causes of chronic mastitis, Gram-negative bacteria found at $23.8 \%$ were 'Salmonella spp, Klebsiella pneumoniae and Mannheimia haemolytica. Salmonella spp was recovered from clinical mastitis at $1.6 \%$, confirm this result was isolated as a cause of mastitis in dairy animals,Klebsiella pneumoniae and Mannheimia haemolytica were isolated in this study with clinical mastitis, this results in agreement with $\left(35,{ }^{10}\right)$, some Mannheimia haemolytica isolated from gangrenous mastitis cases which were in agreement with ${ }^{(38)}$.The results of the study showed an associate between ages of she-camel and occurrence of mastitis, that the age of she-camels were not affected significantly on clinical and subclinical mastitis, this is in agreement with (12) who found the variables age, parity and lactation did not influence in mastitis prevalence, but the high percentage of (5-10) of age may be due to the high percentage of these she-camels in the herds which may reach to $70 \%$ according to this survey. Also results demonstrated camels above 9 years were 
most susceptible for clinical mastitis ${ }^{(37)}$. Shecamels with (5-10 years) old showed a high mastitis percentage since that She-camels were have high milk producing at this age, therefore higher milk content which considered as lines of defense mechanism in mammary gland were lost and low numbers of somatic cell counts are estimated during this age group (38), Increasing mastitis rate with age is probably not due to increased intramammary susceptibility but to increasing ease of penetration of the teat duct by pathogens and accumulated previous infections. Environmental mastitis is controlled through good environmental management, a good milking routine ${ }^{(39)}$. The number of calvings were not affected significantly on clinical mastitis incidence, but the vibration between them was explained that she-camels above 9 years were most susceptible for clinical mastitis, while the aged she-camels group were showed low mastitis incidence may be due to the low percentage of these she-camels in the herds and culling chronically affected she-camels specially that with

\section{References \\ Rerences}

1. Yagil, R. (1988). Endocrine involvment in adaptation to heat and dessication. Exp. Clin. Endrocrinol (7):131-137.

2. Yagil, R.; Zagorski, O.; van Creveld, C.; and Saran, A. (1994). Chameux et dromedaries, animeaux laitiers Science and camel's milk production Ed. Saint Marin, G. Expansion Scientifique Francais, Paris, 75-89.

3. AL-Ani, F. K. (2004). Camel Management and Diseases. /Animal Diseases/Camel/ Infection Diseases .first Edition AL-Sharq Printing Press, Jordan.24: 331-335.

4. Radostits, O.M.; Gay, C.C.; Hinchcliff, K.W.; and Constable, P.D. (2007). Veterinary Medicine, A textbook of the diseases of cattle, horses, sheep, pigs and goats. $10^{\text {th }}$ ed. Elsevier Saunders, Spain.

5. Obeid, A.I. (1983). Field investigation, clinical and laboratory findings on camel mastitis, University of Khartoum, M.V.Sc. thesis. Around Sebeta, Ethiopia . Intern, J. Appl Res Vet Med. 3(4): 113-118.

6. Tibary, A. and Anouassi, A. (2000). Recent Advances in Camelid Reproduction, Skidmore J.A. and multiquarters affected.High mastitis percentage around calving and in early stage of lactation was occurring due to previous mammary gland infection during dry off period can become sever after calving and also the animal immune system is less capable of battling pathogens during the periparturient period and early lactation, besides of gestation and calving stresses. The susceptibility of bacterial species isolated in the present study to the antimicrobial agents used in commercial product. These results are generally showed high susceptibility to most used antimicrobial agents and these our results were in agreement with the finding of (13 and 7). Ciprofloxacin, Doxycycline, Gentamicin and Chloramphenicol were the most effective drugs, these sensitivity results may be due to uncommonly used of antimicrobial agents for camels and the Iraqi nomad not given any importance for camel diseases exception mange and trypanosomiasis.The most isolated bacteria showed greatest resistance for Ampicilline, Erthromycine and Trimethiprime.

Adams G.P. (Eds.) Publisher: International Veterinary Information Service (www.ivis.org).

7. Mody, S. K.; Patel, P. R.; and Prajapati, C. B. (1998). A study on Antimicrobial Susceptibility of Bacteria Isolated from the Mastitic Milk of Rural Camels in India Proceedings of the Third Annual Meeting for Animal Production Under Arid Conditions, (2): 138-144.

8. Barbour,EK.; Nabbut, NH.; Frerichs, WM.; Al Nakhli, HM.; and Al Mukayel, AA.( 1985). Mastitis in Camelus dromedarius in Saudi Arabia. Trop Anim Health Prod. (17):173-9.

9. Bekele T, and Molla B. (2001). Mastitis in lactating camels (Camelus dromedarius), in Afar Region northeastern Ethiopia. Berl Munch Tierarztl Wochenschr. May-Jun. 114(5-6):169-72.

10. Matofari, JW .;Younan, M.; Nanua, J. N.; Mwatha, EW.; and Okemo, PO. (2005). Microorganisms associated with sub-Clinical mastitis and their impact on milk production in camels (Camelus Dromedarius) in semi-arid lands of Northern Kenya. 
International Journal of Agriculture and Rural Development. (6): 182-187.

11. Quandil, SS. and Qudar, J. (1984). Bacteriological study of a few mastitis cases on she-camel (Camelus dromedarius) in United Arab Emirates (Preliminary report). Revue Med Vet. 135: 705-7.

12. Abdurrahman O. A. Sh. (2006). Udder health and milk quality among camels in the Errer valley of eastern Ethiopia, Livestock Research for Rural Development 18 (8): 3-11.

13. Hawari, A.D.; and Hassawi, D.S. (2008). Mastitis in one humped she-camels (Camelus dromedarius), in Jordan. J. Boil. Sci., 8: 958-961.

14. Mohammed,_A.; Molla, B.; RuizBascaran, M.; Abera, B. (2005). A Cross-Sectional Study of Mastitis in Camels (Camelus Dromedarius) In Somali Region, Southeastern Ethiopia Bull Anim. H. 1th. Prod. Afr. 53 (3): 195-201.

15. Jackson, P. G. and Cockcroft, P. D. (2002) Clinical Examination of Farm Animals. First Ed. Ashfordcolour press Lid cosoort. Hauts. Great Britain. (12): 191- 166.

16. Kelly, W. R. (1974). Veterinary clinical diagnosis.2sec ed. The Macmillan publishing company Inc. New York.

17. Younan, M. (2002). Parenteral Treatment of Streptococcus agalactiae Mastitis in Kenyan Camels (Camelus dromedarius) Ev. Méd. vét. Pays trop., 55 (3): 177-181.

18. Woubit, S.; Bayleyegn, M.; Bonnet, P.; and Jean-Baptiste, S. (2001).Camel (Camelus dromedarius) Mastitis in Borena Lowland Pastoral Area,Southwestern EthiopiaRevue Élev. Méd. vét. Pays trop., 54 (3- 4): 207-212.

19. Quinn, P. J.; Carter, M. E.; Markey, B.; and Carter, G. R. (2002).Clinical Veterinary Microbiology, Mosby, Internal Ltd, London. 42- 49.

20. Abera, M.; Abdi, O.; Abunna, F.; and Megersa, B. (2009). Udder health problems and major bacterial causes of camel mastitis in Jijiga, Eastern
Ethiopia: implication for impacting food security Trop Anim Health Prod DOI 10.1007/s11250-009-9424-6.

21. Sori, H.; Zerihun,A. andAbdicho,S.(2005). Dairy Cattle Mastitis In and

22. Yagil, R. (1985).The desert camel: comparative physiological adaptation. Basel; New York: Karger.

23. Rabie, F.O.; AL-Samarrae, N.S.; Saffar, F.J. (1995). General feature of the udder and histological structure of restored and involved mammary gland in one humped Camel. Iraqi J. of vet. Sci. 8 (2): 179-181.

24. Barbour, EK.;Nabbut, NH.; Frerichs, WM.; (1984). Inhibition of pathogenic bacteria by camel's milk: relation to whey lysozyme and stage of lactation. J. Food Prot; 47:838-840.

25. El-Agamy, El.; Ruppaner, R.; and Ismail, A.I. (1992). Antibacterial and antiviral activity of camel milk protective proteins.J.Dairy Res., 59(2).169-175.

26. Farah, Z., (1996). Camel milk: Properties and products. SKAT St. Gallen, Switzerland J. Dairy Sci. 88:30003008.

27. Kappeler, S. (1998).Compositional and structural analysis of camel milk proteins with emphasis on protective proteins.Diss.med. vet., Zürich, Switzerland.

28. Bolbol, A.E.(1982). Mastectomy in shecamel.Assiut Vet. Med. J., 10: 215.

29. 30- Ramadan, R. O.; Hassa, A. M.; R., ElAbdinBey, Y. A.; Algasnawi, Abdulla, E. S. M.; and Fayed, A.A. (1998). Chronic obstructive mastitis in the camel: A clinico-pathological study. Cor. Vet. 77 (2): 132.

30. Hegazy, A.A.; El Dughaym, A.M.; Alaknah, F.M.T.; and Hatem, M.E. (2004).Studies on mastitis in female camel with special reference to brucellosis. J. Camel Sci., 1: 96-102.

31. Hungerford, T.G. (1989). Diseases of livestock. 8th ed hill Book Comp, Sydney.

32. Bakeer. A. M.; Afift, M.; El-Jakee and Hemeda, M. (1994). Pathological and bacteriological studies on mammary gland affections in one humped she- 
camel. Vet. Med. J. Giza. (2): 321326.

33. Jubb.K. V. F. and Kennedy, P. C. (1993).Pathology of domestic animals. V. 111 The Female Genital System 3th Academic Press New York.

34. AL-Ani, F.K.; and AL-Shareefi, M.R. (1997). Studies on mastitis in lactatingone-humped camels (Camelus dromedarius) in Iraq, J. Camel Pract. Res. 4: 47-49.

35. Yagoob, O. Sanaa. (2005). Bacterial Diseases of Reproductive system of camels(Camelus dromedarius) in Eastern sudan J. of Ani. and Vete. Advance 4(7) 642-644.

36. Suchitra Sena, D.; Mal, G.; Kumar, R.; and Sahani, M.S. (2000).A preliminary study of prevalence of mastitis in camel. J. Appl. Anim. Res., 20: 27-31.

37. Ynte, H.S.; David, J.; Francis, W.; Linda, G.T. and Ruben, N.G. (2003)
Monitoring udder health and milk quality using somatic cell counts.Vet.Res.,34:579-596.

38. Jain, N. C. (1979).Common Mammary Pathogens and Factors in Infection and Mastitis. Journal of Dairy Science. 62, (1): 16-22.

39. Fontaine, R.E., Cohen, M.L., Martin, W.T., Vernon, T.M. (1980): Epidemic salmonellosis from cheddar cheesesurveillance and prevention. - Am. J. Epidemiol. 111: 247-254.

40. Kalla, D.J.U.; Mbap, Butswat, S.T.; Abdussamad, A.M.; Ahmed, M.S.; and Okonkwo, I. (2008). Microbiological Examination of Camel (Camelus dromedaries) Milk and Sensitivuty of Milk Microflora to Commonly - Available Antibiotics in Kano Nigeria. Sav. J. Agric. 15979377, (3): 1-8.

\section{دراسة التهاب الضرع ألسريري (الجرثومي) في النوق Camelus) dromedarius)

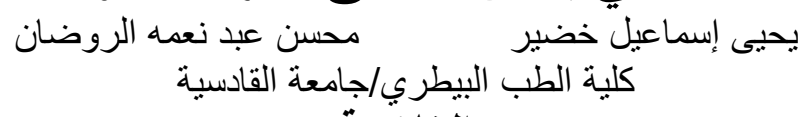

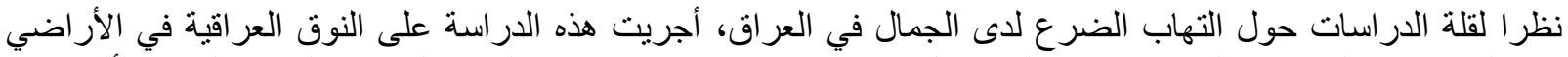

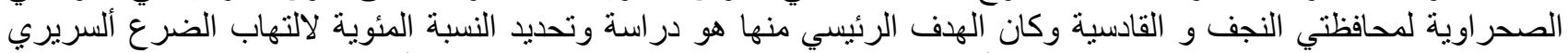

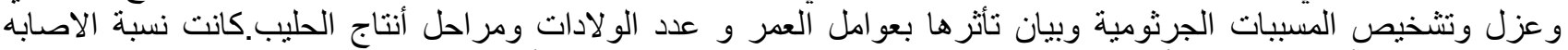

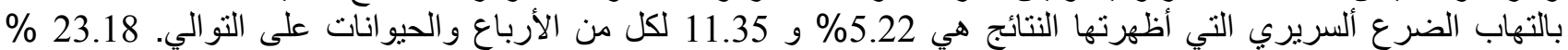

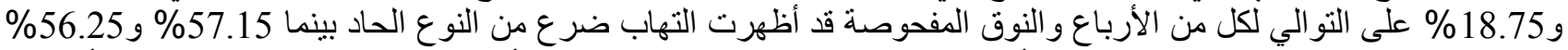

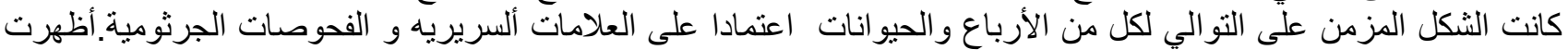

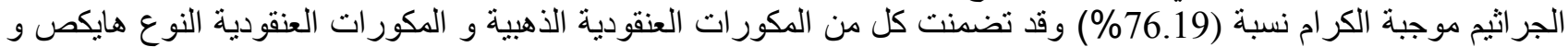

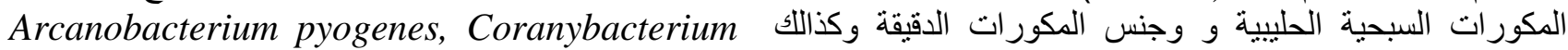

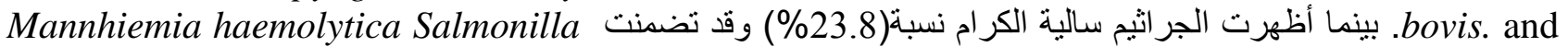
spp and Klibcilla pneumoni

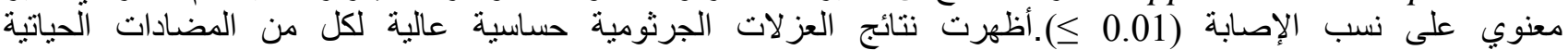
Ciprofloxacin, Doxycycline, Gentamicin, and Tetracycline. Chloramphenicol, sulphthazin/Trimethiprim أظهرت مقاومة لكل من Ampicillin و و 